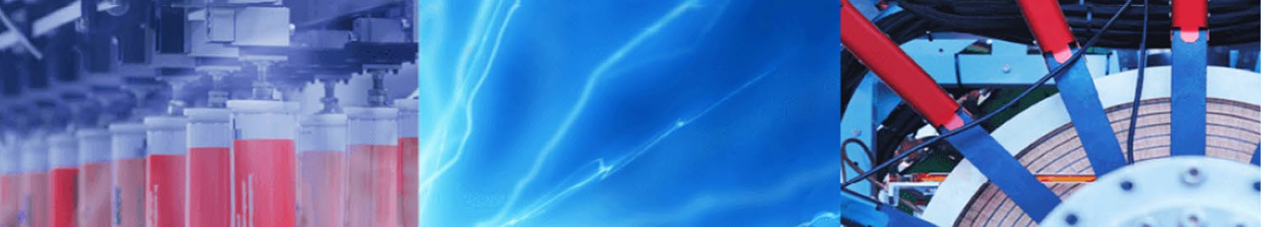

Research Article

\title{
The properties of sludge formed as a result of coagulation of backwash water from filters removing iron and manganese from groundwater
}

\author{
Magdalena Wołowiec ${ }^{1}$ (i) $\cdot$ Alina Pruss ${ }^{2}$ (i) - Małgorzata Komorowska-Kaufman ${ }^{2}$ (D) Iwona Lasocka-Gomuła ${ }^{3}$. \\ Grzegorz Rzepa ${ }^{1}$. Tomasz Bajda ${ }^{1}[0$
}

C The Author(s) 2019 OPEN

\begin{abstract}
The standard groundwater treatment technology is a simple, non-chemical reagent technology based on aeration and filtration processes. This treatment technology is resulted in the formation of groundwater treatment sludge (GWTS). Because one of the elements of sustainable development is the possibility of their reuse, that water treatment plant operators are looking for new ways of managing these sludges. At present, not all factors determining the adsorptive capacity of water treatment sludge are known. The explanation why the adsorption capacity of sludge with a similar structure and chemical composition may differ significantly will allow for their wider use as adsorbents. The information which must be known to ensure proper sludge management are the quality, chemical composition and texture characteristics of the GWTS. The sludges were characterized by X-ray diffraction, X-ray fluorescence, Fourier transform infrared spectroscopy and $\mathrm{N}_{2}$ adsorption/desorption isotherms. The results showed that the composition and properties of the GWTS depend primarily on the quality parameters of the raw water and the processes and reagents used in its treatment technology. GWTS contains mainly amorphous iron oxides. Sludges are characterized by a large specific surface area $\left(145 \mathrm{~m}^{2} / \mathrm{g}\right)$. Due to composition and textural parameters, GWTS demonstrates good adsorption properties toward different compounds such as heavy metals and metalloids. In this article, the authors describe the relationship between properties of resulting sludge and the properties of groundwater, the treatment technology and backwash water treatment from rapid filters.
\end{abstract}

Keywords Filtration · Backwashing · Groundwater · Water treatment residuals · Properties of sludge

\section{Introduction}

The safety of drinking water is a significant issue all over the world. The groundwater is contaminated by iron, manganese, ammonium, nitrate compounds as well as heavy metals and organic matter; however, mainly groundwater is contaminated by iron and manganese compounds [1].
The standard treatment technology for this kind of water is based on aeration and filtration processes [2]. It is a simple, non-chemical reagent technology. If the groundwater quality is poor, additional treatment processes may be required, including the use of chemical reagents. Pollutants deposited in the course of the filtration process are washed out of the filters in the backwashing process and

Magdalena Wołowiec, wolowiec@agh.edu.pl; Alina Pruss, alina.pruss@put.poznan.pl; Małgorzata Komorowska-Kaufman, malgorzata.komorowska-kaufman@put.poznan.pl; Iwona Lasocka-Gomuła, iwona.lasocka-gomula@aquanet.pl; Grzegorz Rzepa, gprzepa@cyf-kr.edu.pl; Tomasz Bajda, bajda@agh.edu.pl | ${ }^{1}$ Faculty of Geology, Geophysics and Environmental Protection, AGH University of Science and Technology, al. A. Mickiewicza 30, 30-059 Kraków, Poland. ${ }^{2}$ Faculty of Civil and Environmental Engineering, Institute of Environmental Engineering, Poznan University of Technology, ul. Berdychowo 4, 60-965 Poznan, Poland. ${ }^{3}$ AQUANET SA, ul. Dolna Wilda 126, 61-492 Poznan, Poland. 
settled in settling tanks forming groundwater treatment sludge (GWTS).

GWTS is produced every day in large quantities around the world [3]. At present, the reuse of sludge from the backwashing of rapid filters used in water treatment processes in Poland is very low compared to other countries. For instance, in Japan and the USA, the percentage of reuse of sludge is 55 and $35 \%$, respectively, while in Poland only $2 \%$. Sludges are applied to municipal sewage systems, in agriculture or in cement production [4]. Regulations that prohibit the introduction of residuals from water treatment processes into surface waters as well as the tightening conditions for their discharge into landfills and the related high costs force water treatment plants to search for new, alternative sludge management methods.

Sludges from water treatment processes (WTS) similarly to fly ash [5], metallurgical slag [6, 7], sewage sludge [8], biomass [9] or reused sanding wastes [10] are waste materials with good adsorption properties toward a range of compounds [3]. Detailed knowledge of the chemical composition of the formed sludge could facilitate its rational utilization. The properties of sludge, such as the surface area, particle size and chemical composition, are among the most important factors determining the possibility of its use as an effective adsorbent for removing a number of pollutants from water and wastewater [11].

The GWTS resulting from the process of iron removal from groundwater contains particles of iron oxyhydroxides with an average diameter of $100 \mathrm{~nm}$ [12]. The sludge particles have an irregular shape and size and form aggregates of a few micrometers in size. As a result, a mesoporous material is obtained and the predominant pore diameter is ca. $6 \mathrm{~nm}$ [13]. The resulting sludge consists mainly of poorly crystalline oxyhydroxides (mainly ferrihydrite) and manganese oxides $[13,14]$. Silica has also been found up to $42 \%$ [12]. In sludge formed from groundwater treatment, the organic matter content is usually very low. Inorganic carbon hardly ever exceeds $0.7 \%$, and organic carbon is only $5.3 \%$ [13]. It should also be noted that the sludge is only slightly polluted with hazardous substances [15]. This is undoubtedly related to the requirements concerning protection zones surrounding the sources of water intended for human consumption.

Water treatment sludge has revealed particularly good adsorption properties with respect to a number of metals and metalloids including arsenic [16], thanks to the enhanced specific surface area comparable with the surface of many commercially available adsorbents. The specific surface area determined on the basis of the BET adsorption model for different GWTS (groundwater treatment sludge) ranged from $120 \mathrm{~m}^{2} / \mathrm{g}$ [13] to $152 \mathrm{~m}^{2} / \mathrm{g}$ [17] when no reagents were used and only $55.3 \mathrm{~m}^{2} / \mathrm{g}[18]$ when coagulation with aluminum and iron salts was involved.
These values do not differ significantly from the specific surface areas of frequently used adsorbents from the group of zeolites and bentonites.

The adsorption capacity and reaction kinetics are influenced not only by the specific surface but also by the chemical composition of the sludge, and its structure varies significantly depending on the sludge origin. GWTS contains poorly crystalline metal oxides which can effectively enhance sorption effectiveness. Due to the high content of iron oxyhydroxides, groundwater treatment sludge shows a high arsenic removal capacity. The $\mathrm{MnO}_{2}$ concentration in the sludge is favorable because it allows the initial oxidation of arsenic, which is usually required before the adsorption process [13]. As(III) is more mobile, toxic and difficult to remove under neutral conditions than $\mathrm{As}(\mathrm{V})$ [17]. It was found that the adsorption capacity of sludge from groundwater treatment process amounted to $132.17 \mathrm{mg} \mathrm{As}(\mathrm{III}) / \mathrm{g}$ and $76.73 \mathrm{mg} \mathrm{As}(\mathrm{V}) / \mathrm{g}$ and was definitely higher than other comparable materials containing $\mathrm{Fe} / \mathrm{Mn}$ oxides [13]. Wu et al. [17] obtained significantly lower arsenite adsorption capacity of the sludge from groundwater treatment equal to $59.7 \mathrm{mg} \mathrm{As}(\mathrm{III}) / \mathrm{g}$ sludge. The arsenic adsorption capacity of sludge accumulated on the filter for iron and manganese removal from groundwater has been demonstrated during the research of the treatment of groundwater containing elevated arsenic concentrations $(26.6 \mu \mathrm{g} / \mathrm{L})[19,20]$. GWTS shows also high sorption capacity toward such heavy metals as $\mathrm{Cd}(\mathrm{II}), \mathrm{Ni}(\mathrm{II})$, $\mathrm{Cu}(\mathrm{II})$ and $\mathrm{Zn}$ (II) [21-23].

At present, not all factors determining the adsorptive capacity of water treatment sludge are known. The explanation why the adsorption capacity of sludge with a similar structure and chemical composition may differ significantly will allow for their wider use as adsorbents.

\section{Methodology}

\subsection{Water treatment plant}

The water treatment plant (WTP) has a maximum water production capacity of $150000 \mathrm{~m}^{3} / \mathrm{d}$. There are three technological lines with a maximum capacity of $50000 \mathrm{~m}^{3} / \mathrm{d}$ each. The WTP is supplied with underground and infiltration waters with a different chemical composition. The groundwater is characterized by high hardness, high concentration of iron and manganese compounds dissolved carbonate, chloride and sulfate ions. The groundwater is sourced from geological layers formed from dead plant remains, transformed by the humification process, whereby the captured waters contain specific dissolved organic matter, while the surface water contains a significant amount of organic compounds, due to the quality of 
the river waters. The collected waters are treated in a technological system based on aeration, first and second stage of rapid filtration, ozonation, and sodium hypochlorite and chlorine dioxide disinfection. Aeration and the concurrent degassing of water take place in an open system of 30 aeration cascades. Some of the iron compounds that have been oxidized are precipitated in the form of flocs falling down to the bottom of the reaction chambers under the cascades. The chambers can also be used for pre-oxidation of iron and manganese compounds. Subsequently, water flows into the second-stage reaction chambers where the active carbon may be dosed in the event of a sudden deterioration of the raw water quality. Thereafter, water is directed to the first-stage filters. Each process line has 10 filtration chambers filled with a fluid double-layer anthracite-quartz filter bed, wherein the processes of iron and manganese removal take place. The total height of the filtration bed is $1.9 \mathrm{~m}(0.4 \mathrm{~m}$ anthracite with grain diameter $d=1.4-2.5 \mathrm{~mm}$ and $1.5 \mathrm{~m}$ quartz sand, $d=0.6-1.4 \mathrm{~mm}$ ). The backwashing process of the first step rapid filters is carried out with hydraulic losses of $160 \mathrm{~cm}$. There are two stages of backwashing, first with air at a capacity of $60 \mathrm{~m}^{3} / \mathrm{m}^{2} \mathrm{~h}$ for 2-3 $\mathrm{min}$, then with water with an intensity increasing from 60 to $72 \mathrm{~m}^{3} / \mathrm{m}^{2} \mathrm{~h}$ in winter and up to $75 \mathrm{~m}^{3} / \mathrm{m}^{2} \mathrm{~h}$ in summer. The expansion at the maximum intensity of backwashing is $30 \%$. The time of this step of backwashing depends on the quality of the raw water and the duration of the filtration cycle and ranges from 8 to $10 \mathrm{~min}$. The first filtrate is directed for further treatment [24]. The final stage of backwashing lasting about 2.5 min consists in a gradual reduction in the water flow rate to approx. $800-900 \mathrm{~m}^{3} / \mathrm{h}$ in order to separate the anthracite and sand layers in the filter bed. The average duration of the filtration cycle is $48-120 \mathrm{~h}$ ( $2-5$ days).

The second stage of water treatment is based on the integrated processes of filtration and ozonation through a biologically active carbon (BAC) filter bed. Its main purpose is to remove dissolved organic matter from water and thereby lower the dose of disinfectants so that the water has a more natural flavor and odor. Ozone is produced from technical oxygen and is dosed into the water in a gaseous form. It oxidizes organic compounds, part of which becomes easily eliminated by microorganisms inhabiting the BAC filter. This is followed by the degassing and pumping of water to carbon filters building. There are eight filter chambers filled with granular activated carbon per each process line, with a bed height of $2 \mathrm{~m}$ each. The filtration chambers are filled with WG-12 activated carbon (manufactured by Gryfskand Sp. z o.o., Hajnówka, Poland) made of low-ash coal, connected by a binder and activated by water vapor (iodine quantity $1100 \mathrm{mg} / \mathrm{g}$, methylene blue adsorption $30 \mathrm{~g} / 100 \mathrm{~g}$, total surface area $1100 \mathrm{~m}^{2} / \mathrm{g}$, particle size $1.5-0.75 \mathrm{~mm}$ ). The maximum hydraulic load of filtration equals $9.0 \mathrm{~m}^{3} / \mathrm{m}^{2} \mathrm{~h}$. After 24 days of operation or when the resistance rises to $1.5 \mathrm{~m} \mathrm{H}_{2} \mathrm{O}$, the filter is backwashed with water and air flow providing depressurization of the filter bed by $35-50 \%[25,26]$.

The backwashing water is discharged via troughs with an inclined bottom. Neither the anthracite-quartz beds nor the BAC filter beds have any supporting layer. It has been possible to omit it thanks to the use of a modern panel drainage system with stainless steel caps [27].

Even when a simple, non-reagent technology of groundwater treatment is used, sludge is formed which, according to the principles of sustainable development, should be processed in order to be suitable for reuse.

\subsection{Technological treatment process of backwash water from the first stage of filtration}

In the process of water treatment, the backwash water from the first-stage filters flows to the surge tanks (Fig. 1a), from where it is pumped to the coagulation stage. The PIX 112-iron (III) sulfate (IV) coagulant is added to the rapid mixing chamber, coupled with two flocculation chambers (Fig. 1b), at an average dose of $100 \mathrm{~g} / \mathrm{m}^{3}$. After $30 \mathrm{~s}$, the backwash mixed with the coagulant flows into the slow mixing chambers. Following a 20-min flocculation period, the backwash flows further to the post-coagulation settling tanks (Fig. 1c), where after sedimentation for $4 \mathrm{~h}$ the treated supernatant liquid flows down by way of gravity to the receiver (the Mosina (anal). The sludge accumulated in the settling tanks is directed to sludge buffer tanks (Fig. 1d). The sludge buffer tanks are equipped with rod stirrers and provide for a possibility of supernatant drainage. The thickened sludge is directed to Bellmer presses (Fig. 1e) where cake ( $40 \%$ dry matter content) is produced. The dehydrated sludge is exported to a wastewater treatment plant, where it is added to the digesters to increase the effectiveness of the elimination of phosphorus compounds [28, 29].

In the time when WTP is supplied with raw water of poor quality, e.g., flood conditions, the water treatment process is enhanced by adsorption on powder activated carbon (PAC), which is dispensed into the water after the aeration process, into the second-stage chambers. In this case, the backwash water containing PAC would be directed first to the settling tanks for backwash water (Fig. 1f) in order to separate the PAC; then, the supernatant would flow into the treatment system. PAC was not used at the time when sludge was sampled for the purpose of the study described herein. 
Fig. 1 The view of the water treatment plant with a maximum water production capacity of $150,000 \mathrm{~m}^{3} / \mathrm{d}$ with the technological process of backwash water treatment. (http://www.ptbnickel.pl/asset s/Uploads/realizacje/budow nictwo-uzytecznosci-publi cznej)

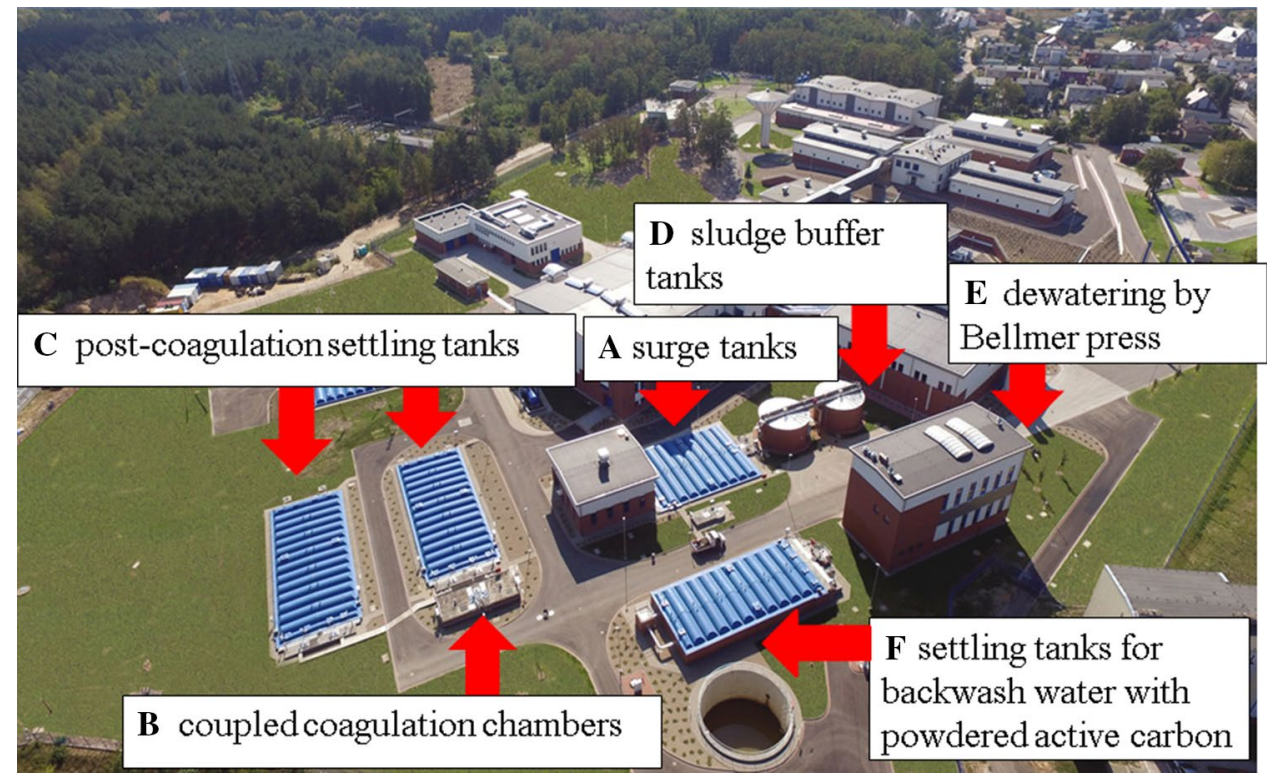

\subsection{Methods}

Analyzes of the water quality changes during treatment process were done throughout the year. The water samples were delivered to accredited laboratory, and all parameters and contaminants concentrations were measured in accordance with standard methods. Sludge sampled was derived from the treatment of backwash from the first-stage filters. The sludge was dried for 4-7 days at $40^{\circ} \mathrm{C}$, grinded in a mortar and sieved using a $1-\mathrm{mm}$ sieve to remove large particles. Then, the GWTS was subjected to phase analysis and its chemical composition and characteristics of the porous texture were also determined. Sludge analyses were performed in AGH-UST laboratories.

The phase analysis was carried out using a SmartLab RIGAKU diffractometer using a copper $X$-ray tube, in the angular range of $2-70^{\circ} 2 \theta$ with a $0.05^{\circ} 2 \theta$ measuring step. To identify mineral phases, the PCPDFWIN ver. 1.30 formalized by JCPDS-ICDD was used. The phases were identified based on the results using the X-RAYAN computer software. The chemical composition of the sludge sample was determined by X-ray fluorescence (WD-XRF) using ZSX Primus II RIGAKU. Qualitative spectral analysis was performed by identifying spectral lines and determining their possible coincidences. Based on this, analytical lines were selected. The semiquantitative analysis was developed using the SQX calculation program. The FTIR analysis was carried out using the Nicolet 6700 Thermo Scientific spectrophotometer, using the DRIFT-Praying Mantis snap-in, with a range of $40-4000 \mathrm{~cm}^{-1}$ and a resolution of $4 \mathrm{~cm}^{-1}$. Preparation: powder sample mixed with $\mathrm{KBr}$ at $2 \%$ by weight relative to $\mathrm{KBr}$. The characteristics of the porous texture were determined on the basis of low-temperature adsorption and nitrogen desorption isotherms at $-196^{\circ} \mathrm{C}$. The analysis was carried out using the ASAP 2020 (Micromeritics) apparatus for precise sorption measurements in a wide range of relative pressures, from approximately $10^{-3}$ to 0.99 . Before the measurement, the samples were heated under vacuum at $105^{\circ} \mathrm{C}$ for $12 \mathrm{~h}$.

The following parameters of the porous texture were calculated for the sample:

1. Specific surface area according to the BrunauerEmmett-Teller methodology (BET)

2. The total pore volume $V_{\text {tot }}^{0.99}$ for the relative pressure $p / p^{0}=0.99$

3. The volume of micropores $V_{\text {mik }}^{D R}$ (pores with a diameter less than $2 \mathrm{~nm}$ ) according to the Dubinin-Radushkevich method.

4. The volume of mesopores $V_{\text {mez }}^{\text {BJH }}$ (pores with a width greater than $2 \mathrm{~nm}$ and less than $50 \mathrm{~nm}$ ) according to the Barrett-Joyner-Halenda (BJH) methodology.

\subsection{Analysis of groundwater samples}

The groundwater treated at the analyzed WTP during the research period ( 1 year) was characterized by iron content ranging from 0.64 to $6.4 \mathrm{mg} \mathrm{Fe} / \mathrm{L}$, the concentration of manganese from 0.46 to $0.79 \mathrm{mg} \mathrm{Mn} / \mathrm{L}$, elevated turbidity from 3.5 to $19 \mathrm{NTU}$ and water color from 7.5 to $15 \mathrm{mg} \mathrm{Pt/L}$. The content of organic compounds (TOC) was quite high, as evident from the following parameters: TOC from 4.4 to $6.4 \mathrm{mg} \mathrm{C/L}$ and UV absorbance at $254 \mathrm{~nm}$ ranged from 58 to $160 \mathrm{~cm}^{-1}$. The concentration of calcium ranged from 86 to $110 \mathrm{mg} \mathrm{Ca} / \mathrm{L}$, of magnesium from 11 to $12 \mathrm{mg} \mathrm{Mg} / \mathrm{L}$ and 
of sodium from 24 to $29 \mathrm{mg} \mathrm{Na} / \mathrm{L}$. Selected parameters of the raw water are presented in Table 1.

\section{Results and discussion}

Treated water during the research period was characterized by low iron concentration from 0.0 to $0.021 \mathrm{mg} \mathrm{Fe} / \mathrm{L}$, manganese concentration from 0.0 to $0.014 \mathrm{mg} \mathrm{Mn} / \mathrm{L}$, turbidity from 0.13 to 0.58 NTU and water color from 0 to $5 \mathrm{mg} \mathrm{Pt/L}$. The content of organic compounds (TOC) ranged from 3.5 to $5.2 \mathrm{mg} \mathrm{C/L}$ and UV absorbance at $254 \mathrm{~nm}$ from 5.7 to $9.7 \mathrm{~m}^{-1}$. Selected parameters of the treated water are presented in Table 2 . Treated water fulfilled the requirements for the quality of drinking water $[30,31]$.

Because usually the backwashing water is discharged to the settling tanks, where the accumulated contaminants
Table 1 Selected raw water parameters

Table 2 Selected treated water parameters

\begin{tabular}{|c|c|c|c|c|c|c|}
\hline \multirow[t]{2}{*}{ Parameter } & \multirow[t]{2}{*}{ Unit } & \multirow{2}{*}{$\begin{array}{l}\text { Number of } \\
\text { analyses }\end{array}$} & \multicolumn{4}{|c|}{ Raw water } \\
\hline & & & Min & Max & Average & SD \\
\hline Color & $\mathrm{mg} \mathrm{Pt/L}$ & 50 & 7.5 & 15.0 & 10.95 & 2.57 \\
\hline Turbidity & NTU & 50 & 3.5 & 19.0 & 8.67 & 3.14 \\
\hline $\mathrm{pH}$ & - & 50 & 7.2 & 7.6 & 7.37 & 0.08 \\
\hline Iron & $\mathrm{mg} / \mathrm{L}$ & 50 & 0.64 & 6.4 & 1.56 & 0.97 \\
\hline Manganese & $\mathrm{mg} / \mathrm{L}$ & 46 & 0.46 & 0.79 & 0.61 & 0.09 \\
\hline Total organic carbon & $\mathrm{mg} \mathrm{C/L}$ & 50 & 4.4 & 6.4 & 4.97 & 0.48 \\
\hline Absorbance at $254 \mathrm{~nm}$ & $\mathrm{~cm}^{-1}$ & 50 & 58 & 160 & 127.4 & 1.09 \\
\hline Copper & $\mu g / L$ & 4 & 0.69 & 1.2 & 0.91 & 0.23 \\
\hline Magnesium & $\mathrm{mg} / \mathrm{L}$ & 4 & 11 & 12 & 11.5 & 0.58 \\
\hline Sodium & $\mathrm{mg} / \mathrm{L}$ & 4 & 24 & 29 & 25.75 & 2.36 \\
\hline Calcium & $\mathrm{mg} / \mathrm{L}$ & 4 & 86 & 110 & 93.75 & 10.97 \\
\hline Nickel & $\mu g / L$ & 4 & 1.7 & 2.3 & 2.1 & 0.29 \\
\hline Lead & $\mu \mathrm{g} / \mathrm{L}$ & 4 & 0.0 & 0.05 & 0.038 & 0.02 \\
\hline Cadmium & $\mu \mathrm{g} / \mathrm{L}$ & 4 & 0.0 & 0.01 & 0.002 & 0.005 \\
\hline Silver & $\mu \mathrm{g} / \mathrm{L}$ & 4 & 0.0 & 0.06 & 0.015 & 0.03 \\
\hline Arsenic & $\mu g / L$ & 4 & 1.5 & 2.9 & 2.3 & 0.6 \\
\hline Vanadium & $\mu g / L$ & 4 & 0.5 & 0.54 & 0.52 & 0.02 \\
\hline Zinc & $\mu \mathrm{g} / \mathrm{L}$ & 4 & 1.2 & 5.2 & 2.9 & 1.8 \\
\hline Chromium & $\mu g / L$ & 4 & 0.0 & 1.0 & 0.048 & 0.06 \\
\hline
\end{tabular}

\begin{tabular}{|c|c|c|c|c|c|c|}
\hline \multirow[t]{2}{*}{ Parameter } & \multirow[t]{2}{*}{ Unit } & \multirow{2}{*}{$\begin{array}{l}\text { Number of } \\
\text { analyses }\end{array}$} & \multicolumn{4}{|c|}{ Treated water } \\
\hline & & & Min & Max & Average & SD \\
\hline Color & $\mathrm{mg} \mathrm{Pt/L}$ & 201 & 0.0 & 5 & 1.41 & 1.36 \\
\hline Turbidity & NTU & 201 & 0.13 & 0.58 & 0.28 & 0.08 \\
\hline $\mathrm{pH}$ & - & 201 & 7.1 & 7.8 & 7.44 & 0.09 \\
\hline Iron & $\mathrm{mg} / \mathrm{L}$ & 51 & 0.0 & 0.021 & 0.009 & 0.005 \\
\hline Manganese & $\mathrm{mg} / \mathrm{L}$ & 47 & 0.0 & 0.014 & 0.005 & 0.002 \\
\hline Total organic carbon & $\mathrm{mg} \mathrm{C/L}$ & 51 & 3.5 & 5.2 & 4.22 & 0.35 \\
\hline Absorbance at $254 \mathrm{~nm}$ & $\mathrm{~cm}^{-1}$ & 51 & 57 & 97 & 73.3 & 8.1 \\
\hline Copper & $\mu \mathrm{g} / \mathrm{L}$ & 4 & 1.6 & 3.4 & 2.8 & 0.8 \\
\hline Magnesium & $\mathrm{mg} / \mathrm{L}$ & 4 & 10 & 12 & 11.25 & 0.95 \\
\hline Sodium & $\mathrm{mg} / \mathrm{L}$ & 4 & 23 & 30 & 26.25 & 2.97 \\
\hline Nickel & $\mu \mathrm{g} / \mathrm{L}$ & 4 & 1.0 & 1.5 & 1.2 & 0.2 \\
\hline Lead & $\mu \mathrm{g} / \mathrm{L}$ & 4 & 0.0 & 0.19 & 0.098 & 0.08 \\
\hline Silver & $\mu \mathrm{g} / \mathrm{L}$ & 4 & 0.0 & 0.17 & 0.043 & 0.09 \\
\hline Arsenic & $\mu \mathrm{g} / \mathrm{L}$ & 4 & 0.0 & 1.0 & 0.89 & 0.09 \\
\hline Chromium & $\mu \mathrm{g} / \mathrm{L}$ & 4 & 0.0 & 0.1 & 0.038 & 0.05 \\
\hline
\end{tabular}


sediment without any additional reagents, the quality of the so-formed sediments (WTS) depends mainly on the chemical composition of the raw water and/or methods and materials used for water treatment.

In the backwash water from the analyzed WTP, the concentration of iron, manganese and suspended matter as well as turbidity and color varied, respectively, in the range: $84-258 \mathrm{mg} \mathrm{Fe} / \mathrm{L}, 1.7-5.6 \mathrm{mg} \mathrm{Mn} / \mathrm{L}, 190-600 \mathrm{mg}$ of dry matter/L, 437-1093 NTU and 1000-1700 mg Pt/L [32]. Such values are typical for backwashing water from deironing and demanganizing filters [33]. In addition to the composition of backwash, the sludge quality is also influenced by its treatment technology. The addition of a coagulation process in this case (PIX 112 dosing) could result in the presence of residual coagulant in the sludge and precipitation of contaminants dissolved in the backwash water. The characteristics of such sludge may be different compared to typical GWTS formed only as a result of suspended solids sedimentation.

The phase analysis of the sludge sampled from the GWTP under review using the XRD method resulted in the identification of the main mineral phases (Fig. 2). The predominant phase was poorly crystalline ferrihydrite $\mathrm{Fe}_{2} \mathrm{O}_{3} \cdot 5 \mathrm{H}_{2} \mathrm{O}$, the presence of which was confirmed by two fuzzy diffraction peaks with maxima of about 2.5-2.6 and $1.5 \AA$ [34]. The sample also contained smaller quantities of quartz and calcite, as well as feldspar. The raising background pattern of the diffractogram indicates the presence of a large number of substances, probably iron compounds, with a low degree of structure order. Other research also confirmed that iron compounds exist mainly in amorphous forms $[13,35,36]$.
The phase composition of sludge was confirmed by XRF analysis. Iron oxides are the predominant chemical components of the sludge sample from the analyzed GWTP (over $43 \%)$. Silica (7.2\%), manganese oxides (3.11\%), calcium oxide (3.93\%) and phosphorus oxide $(4.02 \%)$ are also found. Hence, it is obvious that the chemical composition of sediments is closely related to the composition of raw water and the method of water treatment. Loss of ignition amounts to $36.87 \%$. The detailed composition of the GWTS is shown in Table 3.

The FTIR spectra are shown in Fig. 3. The wide band at $3417 \mathrm{~cm}^{-1}$ was assigned to stretching vibrations of the hydroxyl groups [21,37]. The weak band at $1630 \mathrm{~cm}^{-1}$ was attributed to $\mathrm{H}_{2} \mathrm{O}$ bending vibrations [13]. The bands at 1584 and $1390 \mathrm{~cm}^{-1}$ were assigned to adsorbed carbonates. The broad peak at $1000 \mathrm{~cm}^{-1}$ with a shoulder at $1095 \mathrm{~cm}^{-1}$ is the result of the formation of the binuclear complex between ferrihydrite and sulfate $[38,39]$. The last

Table 3 Chemical composition of the sludge

\begin{tabular}{lrlr}
\hline $\begin{array}{l}\text { Chemical composi- } \\
\text { tion }\end{array}$ & wt\% & $\begin{array}{l}\text { Chemical composi- } \\
\text { tion }\end{array}$ & wt\% \\
\hline $\mathrm{SiO}_{2}$ & 7.20 & $\mathrm{BaO}$ & 0.16 \\
$\mathrm{TiO}_{2}$ & 0.14 & $\mathrm{~K}_{2} \mathrm{O}$ & 0.08 \\
$\mathrm{MnO}$ & 3.11 & $\mathrm{Na}_{2} \mathrm{O}$ & 0.05 \\
$\mathrm{Al}_{2} \mathrm{O}_{3}$ & 0.21 & $\mathrm{SO}_{3}$ & 0.42 \\
$\mathrm{Fe}_{2} \mathrm{O}_{3}$ & 43.65 & $\mathrm{SrO}$ & 0.02 \\
$\mathrm{CaO}$ & 3.94 & $\mathrm{P}_{2} \mathrm{O}_{5}$ & 4.03 \\
$\mathrm{MgO}$ & 0.12 & $\mathrm{LOI}^{*}$ & 36.87 \\
\hline
\end{tabular}

LOI loss of ignition, measured at $950^{\circ} \mathrm{C}$

Fig. 2 X-ray diffraction pattern

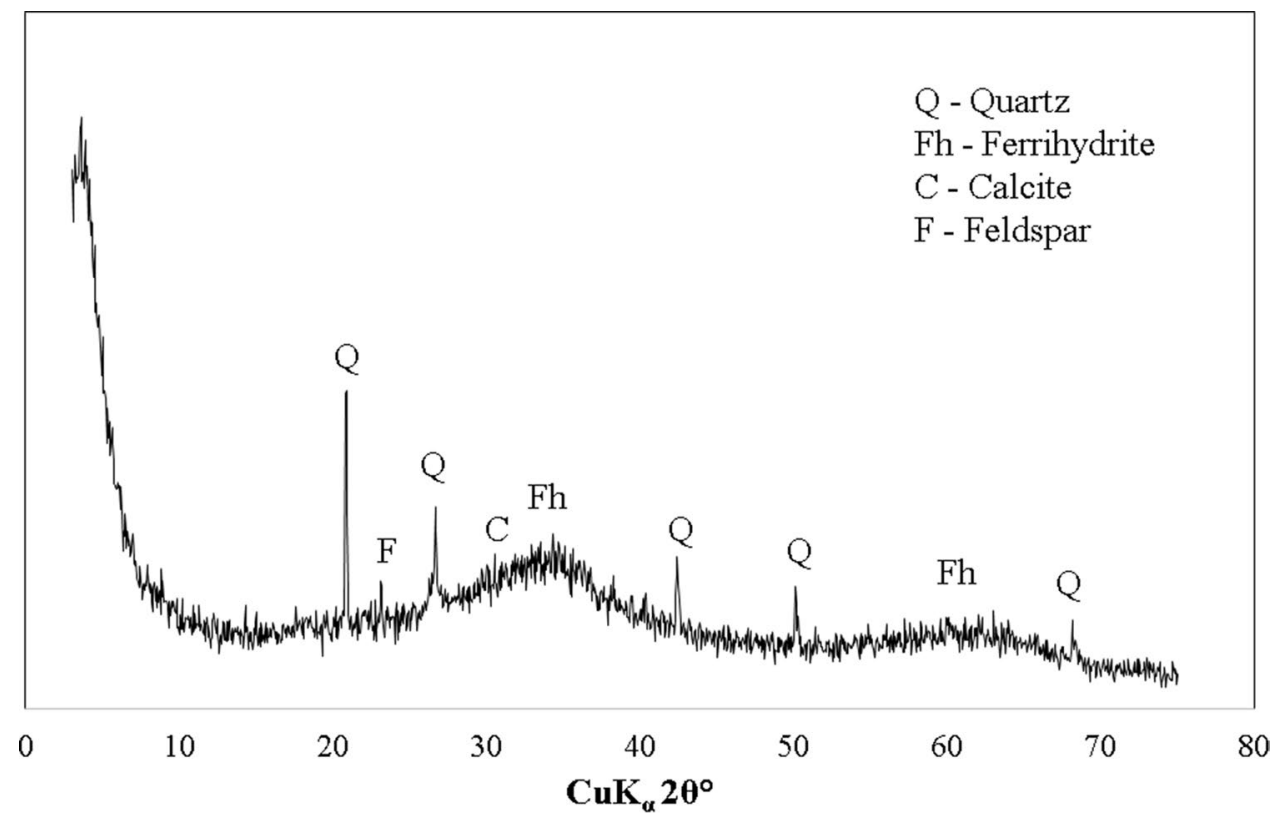

SN Applied Sciences 
Fig. 3 FTIR spectrum

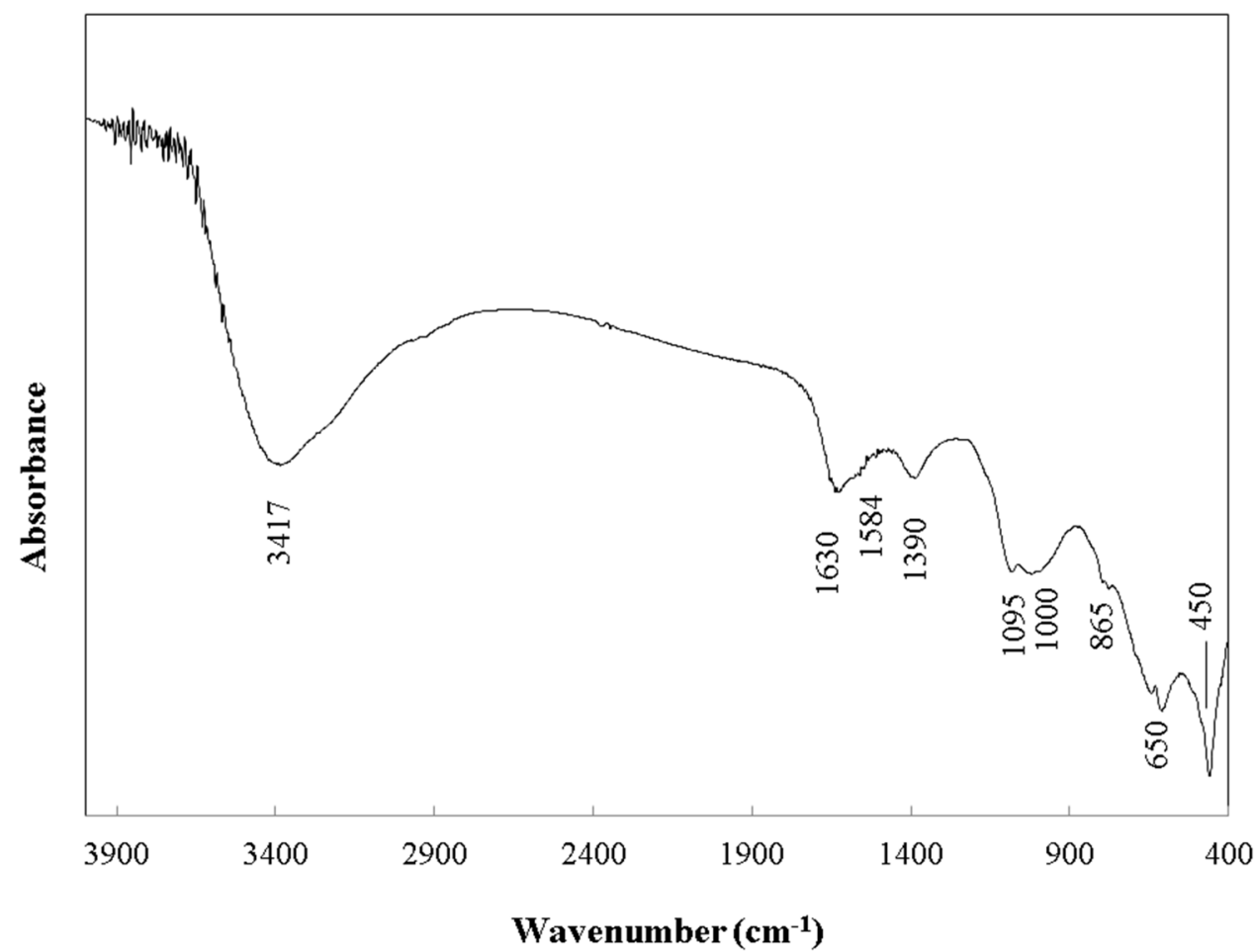

Table 4 Textural parameters of the sludge from the analyzed WTP

\begin{tabular}{lll}
\hline Specific surface & $S_{\text {BET }}\left(\mathrm{m}^{2} / \mathrm{g}\right)$ & 145 \\
Total volume of pores & $V_{\text {tot }}^{0.99}\left(\mathrm{~cm}^{3} / \mathrm{g}\right)$ & 0.191 \\
Total volume of micropores & $V_{\text {mik }}^{\mathrm{DR}}\left(\mathrm{cm}^{3} / \mathrm{g}\right)$ & 0.053 \\
Share of micropores & $V_{\text {mik }}^{\mathrm{DR}} / V_{\text {tot }}^{0.99}$ & 0.277 \\
Total volume of mesopores & $V_{\text {mik }}^{\mathrm{DR}} / V_{\text {tot }}^{0.99}\left(\mathrm{~cm}^{3} / \mathrm{g}\right)$ & 0.113 \\
Share of mesopores & $V_{\text {mez }}^{\mathrm{BJH}} / V_{\text {tot }}^{0.99}$ & 0.592 \\
Total volume of macropores & $V_{\text {mak }}\left(\mathrm{cm}^{3} / \mathrm{g}\right)$ & 0.025 \\
Share of macropores & $V_{\text {mak }}^{\text {BJH }} / V_{\text {tot }}^{0.99}$ & 0.131 \\
\hline
\end{tabular}

strong band at the wave number $450 \mathrm{~cm}^{-1}$ with a shoulder at $650 \mathrm{~cm}^{-1}$ corresponds to $\mathrm{Mn}-\mathrm{O}$ or Fe-O stretching vibrations [13, 37].

Table 4 presents the textural parameters of the sludge. The specific surface area of the water treatment sludge from the GWTP under review calculated using the BET method is $145 \mathrm{~m}^{2} / \mathrm{g}$, which is comparable with the specific surface area of natural and synthetic zeolites used for sorption processes. According to Bandura et al. [40], the specific surface areas of clinoptilolite and the commercial product Damolin reached about $20 \mathrm{~m}^{2} / \mathrm{g}$, respectively, while higher values were obtained in synthetic zeolites (Table 5). The surface areas of the two bentonites were about $50 \mathrm{~m}^{2} / \mathrm{g}$. The surface area of activated carbon is, however, significantly larger. The specific surface area of other adsorbents obtained from industrial waste from the production of aluminum which contains
Table 5 Comparison of the specific surface area of different sorbents

\begin{tabular}{lll}
\hline Sorbent & $\begin{array}{l}\text { Specific surface area } \\
\left(\mathrm{m}^{2} / \mathrm{g}\right)\end{array}$ & References \\
\hline GWTS & 145 & This study \\
Clinoptilolite & 18.3 & {$[40]$} \\
Damolin & 24.1 & {$[40]$} \\
Na-P1 & 74.91 & {$[41]$} \\
Na-X & 282.6 & {$[42]$} \\
Bentonite & 45.2 & {$[43]$} \\
Bentonite & 58.5 & {$[43]$} \\
Activated carbon & $1.360-2.010$ & {$[44]$} \\
Red mud & $58-108$ & {$[45]$} \\
\hline
\end{tabular}

iron oxyhydroxides (so-called red mud) is comparable to that of wastewater treatment sludge.

The share of each class of pores throughout the whole pore volume was as follows: share of micropores- $27.7 \%$, share of mesopores- $59.2 \%$ and share of macropores-13.1\%. The predominance of mesopores in the analyzed sludge sample is confirmed by the nitrogen adsorption and desorption isotherm (Fig. 4). Adsorption isotherms can be classified as type I (the so-called Langmuir isotherm) with $\mathrm{H} 3$ or $\mathrm{H} 2 / \mathrm{H} 3$ hysteresis. Adsorption increases in the range of medium concentrations which indicates pore distribution (mesopores prevail). 
Fig. 4 Isotherms of $\mathrm{N}_{2}$ adsorption and desorption at $-196^{\circ} \mathrm{C}$

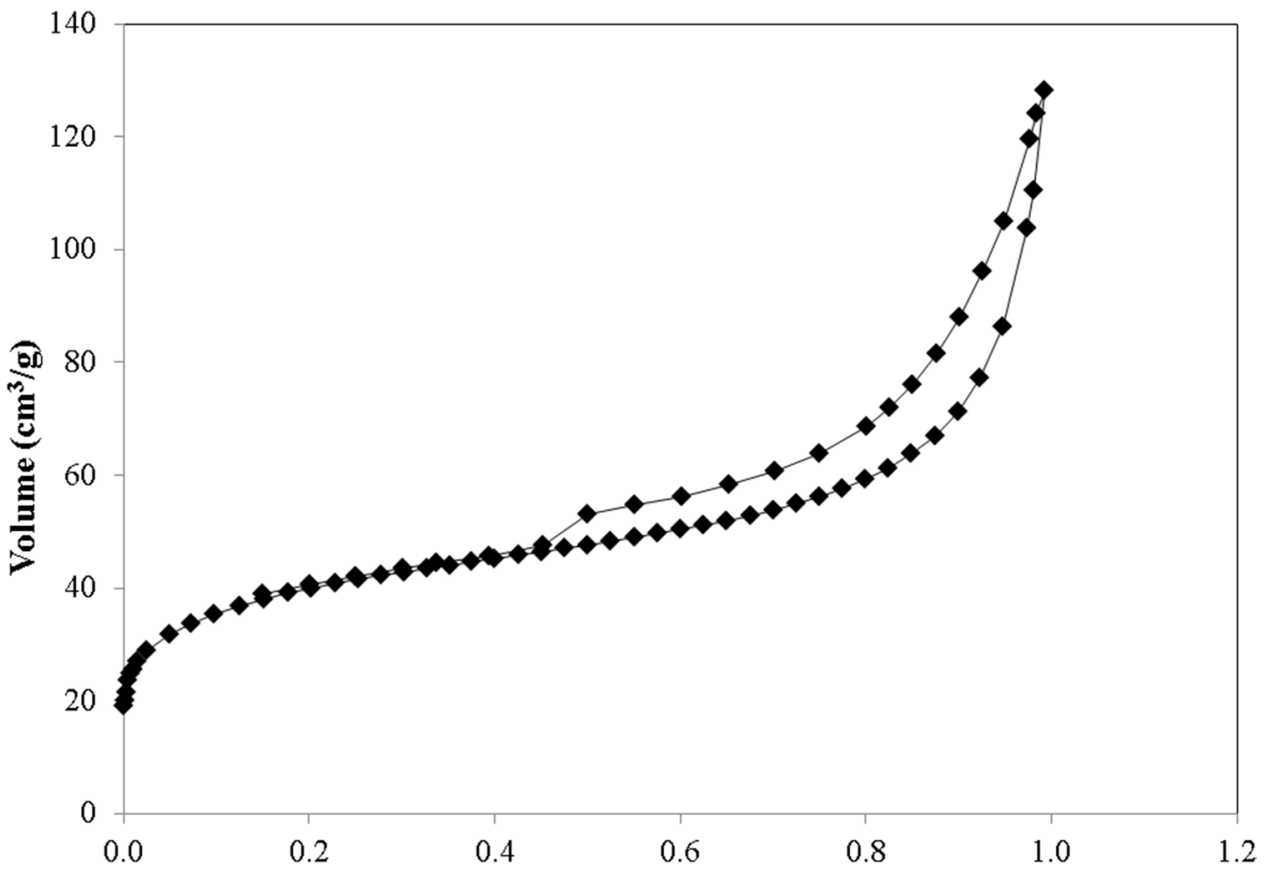

Relative pressure (p/po)
Some of the sludge properties, such as the specific surface area, textural parameters and chemical composition, influence the sorption capability. The sludge exhibited a wide range of specific surface area values which depend on different factors. Particle size is particularly significant in the case of the specific surface area. Caporale et al. [46] have noticed that decreasing the WTS particle sizes from 1000 to $590 \mu \mathrm{m}$ fraction to below $125 \mu \mathrm{m}$ increased the surface area of sludge by almost $80 \%$ in the case of FeWTS. Residuals from groundwater treatment displayed similar values of surface area: $120-170 \mathrm{~m}^{2} / \mathrm{g}$ (Table 6).

The structure and chemical composition of the GWTS, especially the metal oxide concentration, provide acceptable sorption properties, because of the heterogeneous particles with irregular shapes and varying pore diameters. Another factor of key importance is the high content of amorphous oxides in the sludge which increase sorption capabilities in comparison with materials composed of more crystalline forms [47].

\section{Summary}

Even when a simple, non-reagent technology of groundwater treatment is used, sludge is formed which, according to the principles of sustainable development, should be processed in order to be suitable for reuse. The quality, quantity, chemical composition and texture characteristics of the porous sludge formed during water production depend primarily on the quality parameters of raw water and the processes used in its treatment technology. The impact of the backwashing process technology is also very important.

The chemical composition of the sludge sample from the analyzed WTP depends on the quality of raw water and water treatment technology. Due to the fact that iron compounds are the main contamination of treated water, iron oxide is the predominant component of that sample (over $43 \%$ ). The specific surface area of examined sludge
Table 6 Comparison of particle sizes and specific surface areas of GWTS in no-reagent processes

\begin{tabular}{llllll}
\hline Water origin & Water treatment process & Particle size & $\begin{array}{l}\text { Specific surface } \\
\text { area }\left(\mathrm{m}^{2} / \mathrm{g}\right)\end{array}$ & $\mathrm{pH}$ & References \\
\hline Groundwater & No reagents & $<1 \mathrm{~mm}$ & 120 & - & {$[13]$} \\
& No reagents & $<60 \mu \mathrm{m}$ & 152 & 7.0 & {$[17]$} \\
& No reagents & $<1 \mathrm{~mm}$ & 170 & - & {$[14]$} \\
& No reagents $^{\mathrm{a}}$ & $<1 \mathrm{~mm}$ & 145 & - & This study \\
\hline
\end{tabular}

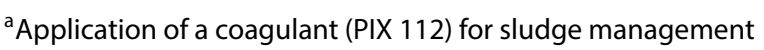


is $145 \mathrm{~m}^{2} / \mathrm{g}$, which is comparable with the specific surface area of natural and synthetic zeolites used for sorption processes. The presence of amorphous iron oxide can be an important factor for the sorption processes.

Application of waste material such as GWTS for sorption processes could be a good and effective sludge management method. However, more research dealing with sorption mechanism and desorption process needs to be conducted as well as sorption experiments of mixtures of selected compounds have to be investigated.

Acknowledgements This work was financed by the National Science Centre, Poland Grant No. 2017/27/N/ST10/00713-Phase, Physicochemical Characterization and Sorption Properties of Ferruginous Sludges Generated from Water Treatment Process and PUT Research Project 01/13/DSPB/0891-High-Effective Methods of Water and Wastewater Treatment and Waste Disposal.

\section{Compliance with ethical standards}

Conflict of interest The authors declare that they have no conflict of interest.

Open Access This article is distributed under the terms of the Creative Commons Attribution 4.0 International License (http://creativeco mmons.org/licenses/by/4.0/), which permits unrestricted use, distribution, and reproduction in any medium, provided you give appropriate credit to the original author(s) and the source, provide a link to the Creative Commons license, and indicate if changes were made.

\section{References}

1. Gude JCJ, Rietveld LC, van Halem D (2017) As(III) oxidation by $\mathrm{MnO}_{2}$ during groundwater treatment. Water Res 111:41-51

2. Štembal T, Markić M, Ribičić N, Briški F, Sipos L (2005) Removal of ammonia, iron and manganese from groundwaters of northern Croatia-pilot plant studies. Process Biochem 40:327-335

3. Babatunde AO, Zhao YO (2007) Constructive approaches toward water treatment works sludge management: an international review of beneficial reuses. Crit Rev Environ Sci Technol 37:129-164

4. Komorowska-Kaufman M, Dymaczewski Z, Jeż-Walkowiak J, Krajewski P, Sozański MM (2016) Zagospodarowanie odpadów z procesów uzdatniania wody. Instal 12:53-58

5. Chen J, Kong H, Wu D, Chen X, Zhang D, Sun Z (2007) Phosphate immobilization from aqueous solution by fly ashes in relation to their composition. J Hazard Mater 139:293-300

6. Kostura B, Kulveitova H, Lesko J (2005) Blast furnace slags as sorbents of phosphate from water solutions. Water Res 39:1795-1802

7. Barca C, Meyer D, Liira M, Driessen P, Comeau Y, Andres Y, Chazarenc $F$ (2014) Steel slag filters to upgrade phosphorus removal in small wastewater treatment plants: removal mechanisms and performance. Ecol Eng 66:214-222

8. Devi P, Saroha AK (2017) Utilization of sludge based adsorbents for the removal of various pollutants: a review. Sci Total Environ 578:16-33

9. Lingamdinne LP, Yang JK, Chang Y-Y, Koduru JR (2016) Low-cost magnetized Lonicera japonica flower biomass for the sorption removal of heavy metals. Hydrometallurgy 165:81-89
10. Lim JW, Chang YY, Yang YK, Lee SM (2009) Adsorption of arsenic on the reused sanding waste calcined at different temperatures. Colloids Surf A Physicochem Eng Asp 345:65-70

11. Komorowska-Kaufman M (2017) Właściowości adsorpcyjne osadów powstających podczas procesów oczyszczania wód podziemnych i powierzchniowych. In: Bajda T (ed) Sorbenty Mineralne 2017: surowce, energetyka, ochrona środowiska, nowoczesne technologie. AGH, Kraków, pp 65-75

12. Zhu S, Fang S, Huo M, Yu Y, Chen Y, Yang X, Geng Z, Wang Y, Bian D, Huo H (2015) A novel conversion of the groundwater treatment sludge to magnetic particles for the adsorption of methylene blue. J Hazard Mater 292:173-179

13. Ociński D, Jacukowicz-Sobala I, Mazur P, Raczyk J, KociołekBalawejder E (2016) Water treatment residuals containing iron and manganese oxides for arsenic removal from water: characterization of physicochemical properties and adsorption studies. Chem Eng J 294:210-221

14. Wołowiec M, Bajda T, Komorowska-Kaufman M, Pruss A, Rzepa $G$ (2018) Removal of heavy metals and metalloids using water treatment residuals as adsorbents. Water supply and water quality, abstract, pp 383-385

15. Siswoyo E, Mihara Y, Tanaka S (2014) Determination of key components and adsorption capacity of a low cost adsorbent based on sludge of drinking water treatment plant to adsorb cadmium ion in water. Appl Clay Sci 97-98:146-152

16. Wołowiec M, Bajda T (2017) Current stage of knowledge relating to the use ferruginous sludge from water treatment plants: a preliminary review of the literature. Mineralogia 48:39-45

17. Wu K, Liu R, Li T, Liu H, Peng J, Qu J (2013) Removal of arsenic (III) from aqueous solution using a low-cost by-product in Feremoval plants-Fe-based backwashing sludge. Chem Eng J 226:393-401

18. Wang C, Yuan N, Bai L, Jiang H-L, Pei Y, Yan Z (2016) Key factors related to drinking water treatment residue selection for adsorptive properties tuning via oxygen-limited heat treatment. Chem Eng J 306:897-907

19. Postawa A, Jeż-Walkowiak J, Pruss A, Wątor K (2011) Arsen w wodach podziemnych okolic Lublina. Biuletyn Państwowego Instytutu Geologicznego 445:495-503

20. Komorowska-Kaufman M, Pruss A, Jeż-Walkowaik J, Postawa A, Wątor K (2012) Usuwanie żelaza, manganu i arsenu z wód podziemnych z okolic Lublina. In: Dymaczewski Z, Jeż-Walkowiak J (eds) Water supply and water quality. Polskie Zrzeszenie Inżynierów i Techników Sanitarnych Oddział Wielkopolski, Poznań, pp 371-382

21. Siswoyo E, Mihara Y, Tanaka S (2014) Determination of key components and adsorption capacity of a low-cost adsorbent based on sludge of drinking water treatment plant to adsorb cadmium ion in water. Appl Clay Sci 97-98:146-152

22. Ong DC, Kan CC, Pingul-Ong SMB, de Luna MDG (2017) Utilization of groundwater treatment plant (GWTP) sludge for nickel removal from aqueous solutions: isotherm and kinetic studies. J Environ Chem Eng 5:5746-5753

23. Ngatenah SNI, Kutty SRM, Isa MH (2010) Optimization of heavy metal removal from aqueous solution using groundwater treatment plant sludge (GWTPS). In: International conference on environment (ICENV 2010)

24. Lasocka-Gomuła I, Ćwiklak B, Weber $\measuredangle$ (2011) Modernizacja SUW Mosina. Wybrane aspekty eksploatacyjne i techniczne Część I. Płukanie filtrów antracytowo-kwarcowych. Technol Wody 6:47-52

25. Kołaski P, Wysocka A, Pruss A, Lasocka-Gomuła I, Michałkiewicz M, Cybulski Z (2017) Usuwanie związków organicznych podczas filtracji wody. In: Bergier T, Włodyga Bergier A (eds) Dezynfekcja wody: zagrożenia, wyzwania, nowe technologie. AGH, Kraków, pp 195-201 
26. Kołaski P, Wysocka A, Pruss A, Lasocka-Gomuła I, Michałkiewicz M, Cybulski Z (2018) Usuwanie związków organicznych podczas filtracji wody przez złoża biologicznie aktywnych filtrów węglowych - badania w skali technicznej. Technol Wody 5(61):8-15

27. Pruss A, Pruss P, Jedrzejczak A (2011) Hydraulic losses generated by modern drainage systems during backwash of rapid filters. Ochr Sr 33(4):47-48

28. Zimoch I, Lasocka-Gomula I (2015) Potential operational effectiveness of backwash water recirculation in groundwater treatment train of mosina plant near Poznan. Ochr Sr 3(3):49-55

29. Jaroszyński T, Krajewski P, Grześkowiak K (2011) Praktyczne wykorzystanie osadów żelazowych z procesów uzdatniania wody. Technol Wody 2:26-33

30. Recast of Drinking Water Directive (Council Directive 98/83/EC of 3 November 1998 on the quality of water intended for human consumption), 2018

31. The Regulation of the Minister of Health of March 29, 2007, as amended on December 7, 2017 changing Regulation on the quality of drinking water for man, Warsaw, Poland Government Publishing Service

32. Małgorzata Komorowska-Kaufman, Iwona Lasocka-Gomuła (2018) Charakterystyka wód popłucznych z filtrów do odżelaziania i odmanganiania wód podziemnych i sposoby ich oczyszczania. Technol Wody 6(62):24-29

33. Wiercik $P$ (2011) Badania nad oczyszczaniem popłuczyn powstających podczas płukania filtrów do odżelaziania i odmanganiania wody. Dissertation, Uniwersytet Przyrodniczy we Wrocławiu, Wrocław

34. Ahmad A, Cornellissen E, van de Watering S, van Tijk T, van Genuchten C, Bundschuh J, van der Wal A, Bhattacharya P (2018) Arsenite removal in groundwater treatment plants by sequential Permanganate-Ferrictreatment. J Water Process Eng 26:221-229

35. Romão LPC, Lead JR, Rocha JC, Oliveira LC, Rosa AH, Mendonça AGR, Ribeiro AS (2007) Structure and properties of Brazilian peat: analysis by spectroscopy and microscopy. J Braz Chem Soc $14: 714-720$

36. Zhang R, Leiviskä T, Tanskanen J, Gao B, Yue Q (2019) Utilization of ferric groundwater treatment residuals for inorganicorganic hybrid biosorbent preparation and its use for vanadium removal. Chem Eng Sci 361:680-689
37. Kan CC, Ibe AH, Rivera KKP, Arazo RO, de Luna MDG (2017) Hexavalent chromium removal from aqueous solution by adsorbents synthesized from groundwater treatment residuals. Sustain Environ Res 27:163-171

38. Vempati RK, Loeppert RH (1989) Influence of structural and adsorbed $\mathrm{Si}$ on the transformation of synthetic ferrihydrite. Clays Clay Miner 37:273-279

39. Rzepa G, Pieczara G, Gaweł A, Tomczyk A, Zalecki R (2016) The influence of silicate on transformation pathways of synthetic 2-line ferrihydrite. J Therm Anal Calorim 125:407-421

40. Bandura L, Franus M, Józefaciuk G, Franus W (2015) Synthetic zeolites from fly ash as effective mineral sorbents for land-based petroleum spills cleanup. Fuel 147:100-107

41. Wołowiec M, Muir B, Bajda T, Zięba K, Kijak B, Franus W (2017) Removal of BTEX and hexane by organo-zeolites: the influence of surfactants carbon chain length on the sorption process. Desalin Water Treat 94:120-128

42. Wołowiec M, Muir B, Zięba K, Bajda T, Kowalik M, Franus W (2017) Experimental study on the removal of VOCs and PAHs by zeolites and surfactant-modified zeolites. Energy Fuels 31:8803-8812

43. Góra W, Góra P, Jaszczyszyn K (2016) Perspektywy zastosowania naturalnych bentonitów w technologii ścieków przemysłowych. Ochr Sr 18:940-951

44. Choma J, Jaroniec M, Ustinov EA (2004) Adsorpcyjna charakterystyka węgli aktywnych o bardzo dobrze rozwiniętej porowatości. Ochr Sr 4:3-7

45. De Gisi S, Lofrano G, Grassi M, Notarnicola M (2016) Characteristics and adsorption capacities of low-costs sorbents for wastewater treatment: a review. SM\&T 578:16-33

46. Caporale AG, Punamiya P, Pigna M, Violante A, Sarkar D (2013) Effect of particle size of drinking-water treatment residuals on the sorption of arsenic in the presence of competing ions. J Hazard Mater 260:644-651

47. Dixit S, Hering JG (2003) Comparison of arsenic (V) and arsenic (III) sorption onto iron oxide minerals: implications for arsenic mobility. Environ Sci Technol 37:4182-4189

Publisher's Note Springer Nature remains neutral with regard to jurisdictional claims in published maps and institutional affiliations. 